\title{
Trichilemmoma Arising in a Sebaceous Nevus Successfully Treated with Cryotherapy
}

\author{
Jamal Alqahtani, Sahar Hassan Al-Natour \\ Department of Dermatology, College of Medicine, Imam Abdulrahman Bin Faisal University, Dammam, Eastern Province, Saudi Arabia \\ Correspondence: Jamal Alqahtani, Email jamqahtani@iau.edu.sa; jamal-al-qahtani@hotmail.com
}

\begin{abstract}
Nevus sebaceous of Jadassohn (NSJ) is a benign congenital hamartoma composed of follicular, adnexal appendages and epidermal hyperplasia. Various secondary neoplasms, mostly adnexal in origin, can arise within nevus sebaceous. We report the case of a 16-year-old female who had NSJ associated with trichilemmoma, which was successfully treated with cryotherapy. We found cryotherapy to be an effective, satisfactory therapy, with acceptable cosmetic results, especially for patients who have visible lesions that can be easily followed.
\end{abstract}

Keywords: nevus sebaceous of Jadassohn, trichilemmoma, cryotherapy

\section{Introduction}

Nevus sebaceous of Jadassohn (NSJ) is a benign congenital verrucous hamartoma composed of follicular, sebaceous and apocrine appendages, varying from a few millimeters to several centimeters in diameter. The solitary lesion is typically present at birth near the vertex of the scalp and face as a subtle or slightly raised lesion, which progressively thickens throughout life, becoming verrucous in adulthood. ${ }^{1,2}$ Various secondary neoplasms, mostly adnexal in origin, can arise within nevus sebaceous. Deletion of the $P T C H$ gene has been identified in nevus sebaceous and may be responsible for the predisposition to the development of basal cell carcinoma and other neoplasms, ${ }^{3}$ thus requiring local excision, ${ }^{4}$ carbon dioxide $\left(\mathrm{CO}_{2}\right)$ ablative laser therapy ${ }^{5}$ or argon and erbium yttrium-aluminum-garnet (Er:YAG). ${ }^{6,7}$

Upon review of the literature, we did not find any reports of NSJ treated with cryotherapy. We report a case of NSJ associated with trichilemmoma successfully treated with cryotherapy.

\section{Case Report}

A 16-year-old female presented to the dermatology clinic at King Fahd Hospital of the University, Saudi Arabia, with a history of rough lesions over the upper lip since early childhood. Initially, the lesion comprised raised skin-colored papules, which had gradually thickened over the past 3 years in a linear configuration. A dermatological examination revealed a $3 \times 1 \mathrm{~cm}$ skin-colored linear verrucous plaque over the left upper lip (Figure 1). Systemic examination was unremarkable. Differential diagnosis includes epidermal nevus, nevus sebaceous and verruca vulgaris.

Skin biopsy revealed hyperkeratosis and papillomatosis with exophytic papillary projections of pale eosinophilic basaloid cells. The dermis showed a proliferation of immature sebaceous glands with vacuolated cytoplasm. Collectively, these are features of nevus sebaceous with coexisting trichilemmoma (Figure 2A-C).

Local excision was suggested to the patient owing to the risk of malignant transformation. However, she opted to undergo cryotherapy rather than local excision because of cosmetic concerns about scarring that may result from the surgery. Accordingly, the patient underwent eight sessions of liquid nitrogen cryotherapy in the form of three freeze-thaw cycles for 20-30 seconds per session over a period of 2 months, with a good cosmetic result and softening of the lesions (Figure 3). The patient has just finished 1 year of follow-up and is currently under active surveillance for any worrisome changes. 


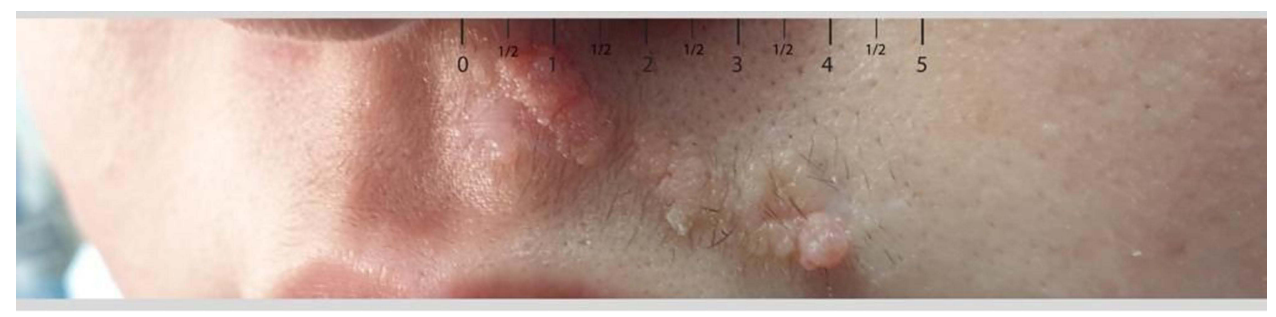

Figure I NSJ before treatment.

\section{Discussion}

NSJ is a benign congenital hamartoma composed of follicular, adnexal appendages and epidermal hyperplasia. It usually presents at birth as a well-circumscribed, yellowish lesion that can vary in size. It commonly affects the scalp and face. The lesions are usually slightly elevated, with a hairless and velvety surface at an earlier age. However, when the pilosebaceous structures mature during puberty, the lesions can become progressively verrucous and thickened. ${ }^{1,2}$

Various secondary neoplasms can arise within nevus sebaceous, which are mostly adnexal in origin. A retrospective study by Idriss and Elston reviewed 707 cases of nevus sebaceous and reported the occurrence of secondary neoplasms among $21.4 \%$ of their cases. Benign neoplasms accounted for $18.9 \%$ of their cases, in contrast to $2.5 \%$ of cases with malignant tumors. The most common secondary benign neoplasm was trichoblastoma (34.7\%), followed by syringocystadenoma papilliferum (24.7\%). Trichilemmoma accounted for 5.3\% of the neoplasms. The most common malignant neoplasm was basal cell carcinoma, which accounted for 5.3\% of all neoplasms. ${ }^{8}$

There have been different approaches in the management of the nevus sebaceous, especially since no consensus has been reached regarding the need for prophylactic excision. ${ }^{9-11}$ Still, Rosen et al recommended that all nevus sebaceous lesions should be excised owing to the risk of malignant transformation, although they emphasized the morbidity associated with anesthesia and excision. ${ }^{9}$ Kamyab-Hesari et al, on the other hand, recommended only close follow-up for all children with nevus sebaceous. ${ }^{10}$ Many other authors have recommended an individualized approach, especially for patients who have visible lesions that can be easily followed. ${ }^{11}$

Since the benefits of surgical excision are still debatable and the risk of malignant transformation is low, we found cryotherapy to be an effective, satisfactory therapy with acceptable cosmetic results, especially in young female adolescents who wish to avoid more invasive intervention.

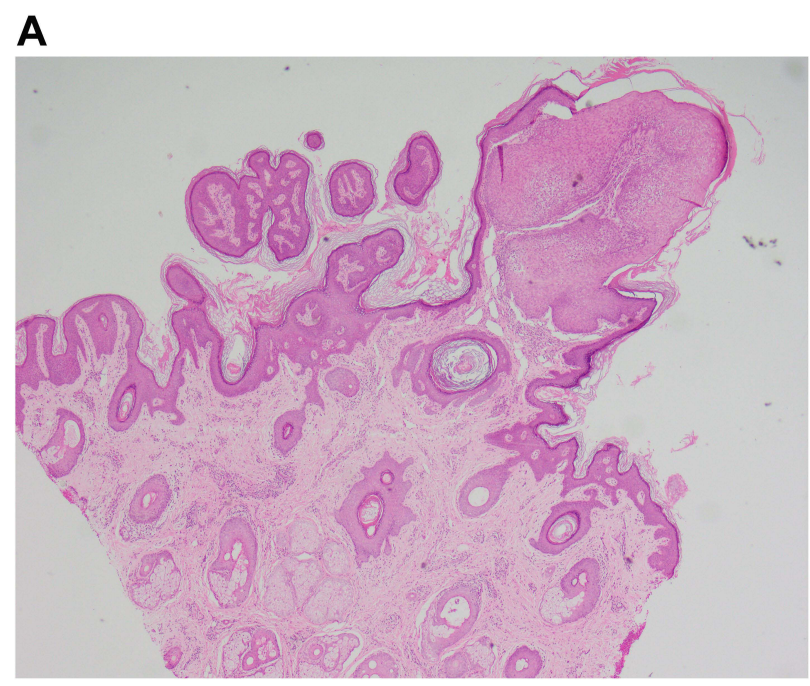

Figure 2 Continued. 


\section{B}

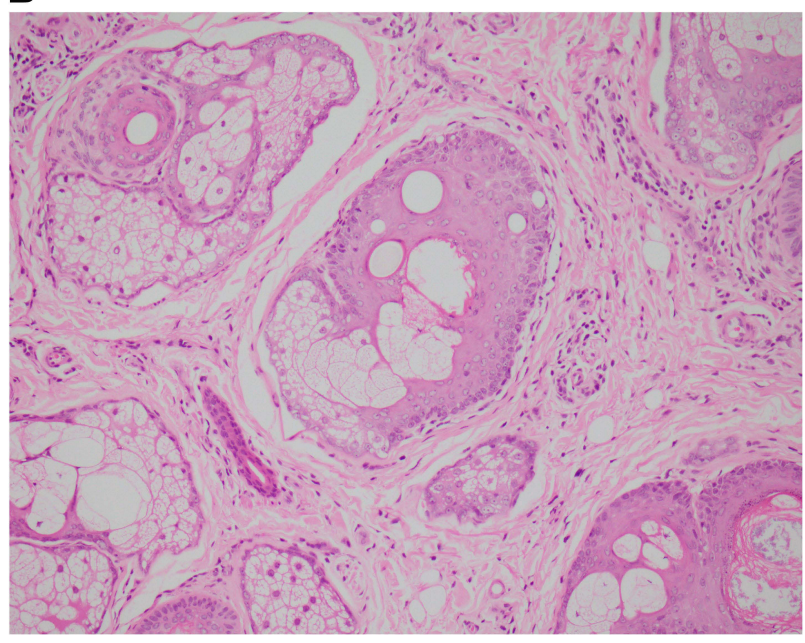

C

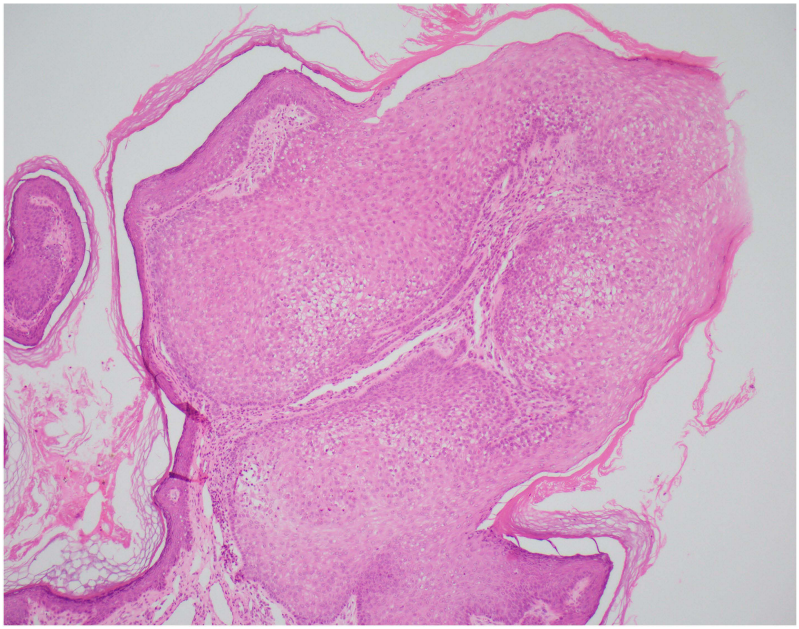

Figure 2 (A) Nevus sebaceous with overlying trichilemmoma: sebaceous gland proliferation in the dermis with overlying papillomatous projection of eosinophilic basaloid cells $(\mathrm{H} \& E, \times 40)$. (B) Sebaceous hyperplasia with vacuolated cytoplasm (H\&E, $\times 200)$. (C) Trichilemmoma exophytic papillomatous projection of clear eosinophilic cuboidal palisaded cells $(\mathrm{H} \& \mathrm{E}, \times 100)$.

\section{Conclusion}

Cryotherapy is an optional treatment modality in NSJ, especially for patients who have visible lesions that can be easily followed, with acceptable cosmetic results. Further systemic studies should be conducted to ascertain the effectiveness of cryotherapy in the treatment of NSJ with long-term follow-up.

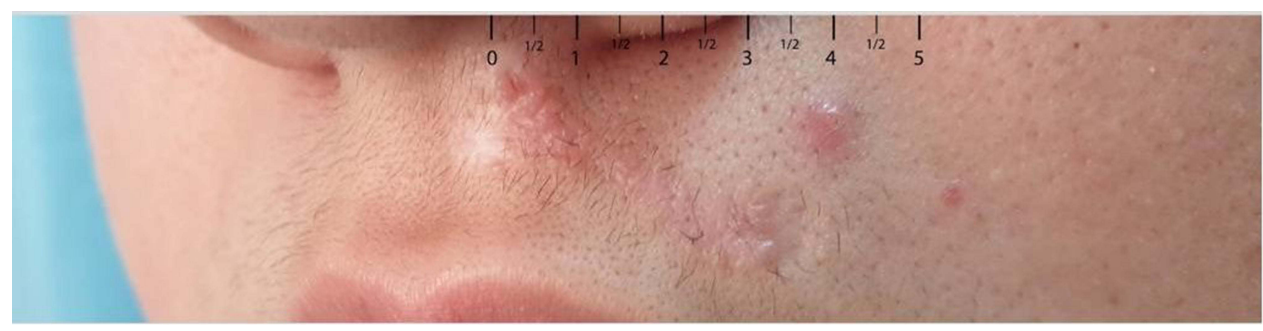

Figure 3 NSJ after eight sessions of cryotherapy. 


\section{Ethics and Consent Statement}

Signed consent was obtained from the family member for the publication of the case details and accompanying images. Institutional approval was not required to publish the case details.

\section{Acknowledgment}

We would like to acknowledge Dr. Mohammed J. Alyousef for the histopathology images.

\section{Author Contributions}

Both authors contributed to data analysis, drafting or revising the article, have agreed on the journal to which the article was submitted, gave final approval of the version to be published, and agree to be accountable for all aspects of the work.

\section{Disclosure}

The authors report no conflicts of interest in this work.

\section{References}

1. Bolognia J, Cerroni L, Schaffer JV. Dermatology. 4th ed. Philadelphia: Elsevier; 2018.

2. James WD, Elston DM, Berger TG. Andrews' Diseases of the Skin: Clinical Dermatology. 12th ed. Philadelphia, PA: Elsevier; 2016.

3. Xin H, Matt D, Qin JZ, Burg G, Böni R. The sebaceous nevus: a nevus with deletions of the PTCH gene. Cancer Res. 1999;59(8):1834-1836.

4. Margulis A, Bauer BS, Corcoran JF. Surgical management of the cutaneous manifestations of Linear nevus sebaceus syndrome. Plast Reconstr Surg. 2003;111:104. doi:10.1097/01.PRS.0000046246.50517.A6

5. Ashinoff R. Linear nevus sebaceus of Jadassohn treated with the carbon dioxide laser. Pediatr Dermatol. 1993;10:189-191.

6. Ginsbach G. Nevus sebaceous: treatment with argon laser. Hautarzt. 1980;31:338-339.

7. Aithal V. Nevus sebaceous: response to erbium YAG laser ablation. Indian J Plast Surg. 2005;38:48-50. doi:10.4103/0970-0358.16497

8. Idriss MH, Elston DM. Secondary Neoplasms associated with Nevus sebaceous of Jadassohn: a study of 707 cases. J Am Acad Dermatol. 2014;70 (2):332-337. doi:10.1016/j.jaad.2013.10.004

9. Rosen H, Schmidt B, Lam HP, et al. Management of Nevus Sebaceous and the risk of basal cell carcinoma: an 18-year review. Pediatr Dermatol. 2009;26(6):676-681. doi:10.1111/j.1525-1470.2009.00939.x

10. Kamyab-Hesari K, Seirafi H, Jahan S, et al. Nevus Sebaceous: a clinicopathological study of 168 cases and review of the literature. Int J Dermatol. 2016;55(2):193-200. doi:10.1111/ijd.12845

11. Moody MN, Landau JM, Goldberg LH. Nevus sebaceous revisited. Pediatr Dermatol. 2012;29(1):15-23. doi:10.1111/j.1525-1470.2011.01562.x

Clinical, Cosmetic and Investigational Dermatology is an international, peer-reviewed, open access, online journal that focuses on the latest clinical and experimental research in all aspects of skin disease and cosmetic interventions. This journal is indexed on CAS. The manuscript management system is completely online and includes a very quick and fair peer-review system, which is all easy to use. Visit http://www. dovepress.com/testimonials.php to read real quotes from published authors.

Submit your manuscript here: https://www.dovepress.com/clinical-cosmetic-and-investigational-dermatology-journal 